\title{
The Role of Family Welfare Movement Team (TP-PKK) in Creating Child Protection in Fulfillment of Education Rights During the Covid-19 Pandemic
}

\author{
Yenny Aman Serah', Anita Yuliastini' ${ }^{2}$ Rini Setiawati ${ }^{3}$, Sri Ayu Septinawati ${ }^{4}$ \\ ${ }^{1,2}$ Faculty Of Law, Universitas Panca Bhakti Pontianak \\ 3,4, Middle Law Instructor, Ministry of Law and Human Rights Regional Office, West Kalimantan \\ ${ }^{1}$ yenny.upb@gmail.com, ${ }^{2}$ rini090366@gmail.com, \\ 3anitayuliastinj1979@gmail.com, ${ }^{4}$ septin2006@yahoo.co.id
}

\author{
Article submitted : February, 23, 2021 \\ Article Reviewed : August, 20, 2021 \\ Articcle Accepted : December, 10, 2021
}

\begin{abstract}
Covid-19 has a significant impact on the life of the Indonesian, including fulfilling the right to education for children. With the social distancing, the Ministry of Education in Indonesia issued a policy by closing schools and replacing the teaching and learning process using an online system. However, there are obstacles during online learning. One of them is parents' unpreparedness to accompany their children. It is necessary to build motivation for parents or families, especially mothers. Children as the goal of education and the realization of child protection have been regulated in legislation. The authors conducted the community service activity with an online legal counseling method to Family Welfare Movement Team (here and after called TP-PKK) in Regency/City throughout West Kalimantan. In conclusion, TP-PKK has a role in creating child protection in fulfillment of education rights during the Covid-19 pandemic. Legal counseling could be carried out widely and sustainably to motivate parents or families to assist their children in the online learning process, so child protection is realized.
\end{abstract}

Keywords: covid-19; fulfillment of education rights; child protection; the role of TP-PKK

Abstrak
Covid-19 berdampak signifikan bagi kehidupan bangsa Indonesia, termasuk pemenuhan hak atas pendidikan bagi anak. Dengan adanya social distancing, Kementerian Pendidikan Indonesia mengeluarkan kebijakan dengan menutup sekolah dan mengganti proses belajar mengajar dengan sistem online. Namun, ada kendala selama pembelajaran online. Salah satunya adalah ketidaksiapan orang tua untuk mendampingi anaknya. Untuk itu perlu dibangun motivasi bagi orang tua atau keluarga khususnya ibu. Anak sebagai tujuan pendidikan dan perwujudan perlindungan anak telah diatur dalam peraturan perundang-undangan. Penulis melakukan kegiatan pengabdian masyarakat dengan metode penyuluhan hukum online kepada Tim Gerakan Keluarga Sejahtera (selanjutnya disebut TP-PKK) di Kabupaten/Kota se-Kalimantan Barat. Kesimpulannya, TP-PKK memiliki peran dalam menciptakan perlindungan anak dalam pemenuhan hak pendidikan di masa pandemi Covid-19. Penyuluhan hukum dapat dilakukan secara luas dan berkelanjutan untuk memotivasi orang tua atau keluarga untuk mendampingi anaknya dalam proses pembelajaran online, sehingga terwujud perlindungan anak.

Kata kunci: covid-19; pemenuhan hak pendidikan; Perlindungan anak; peran TP-PKK

\section{INTRODUCTION}

Covid-19 is a virus from the Coronaviridae family, a family of SARS-CoV and MERS-CoV viruses (Isbaniah and Susanto, 2020). This disease started to become a pandemic in 2019-2020 with transmission 
through droplets from the respiratory tract (Nurkholis, 2020). The prevalence of the Covid 19 virus spread to all ages, from teenagers to the elderly. The pandemic impacts economy, politics, health, society, and religion, including education (Harirah, 2020). More than 370 million children and adolescents do not study offline due to school closures as an effort to break the chain of the spread of COVID-19, resulting in psychological trauma that demotivates them in learning (Nurkholis, 2020).

This condition requires parents to accompany their children in the online learning process. Therefore, it is necessary to hold counseling to motivate parents to prioritize the conception of child protection, especially the right to education, by involving the role of the West Kalimantan TP-PKK (Family Welfare Movement Team). The Counselling provided enlightenment regarding child protection to the grassroots community or family. As a result, Mothers can optimize the process of character building, especially at the elementary school-age level children.

\section{GENERAL DESCRIPTION OF COMMUNITY, PROBLEMS, AND TARGET SOLUTIONS}

\section{General Description}

Due to the COVID-19 pandemic, social changes have taken place in the social order of life in society, including the world of education. Face-to-face learning in schools suddenly undergoes a very drastic change. The Ministry of Education in Indonesia issued a policy by closing schools and replacing the teaching and learning process using an online system. Previous research showed that students and teachers sometimes face various problems during online learning. For example, the teachers had not completed the learning materials, and then teachers replaced them with tasks. The students complained that teachers give more assignments (Siahaan, 2020). However, online learning is also has a positive impact. Students and teachers can master technology. In the era of increasingly sophisticated technological disruption, individuals must have the ability to learn technology.

\section{Problems}

A recent study revealed that ineffective learning in elementary school students during the COVID-19 pandemic was due to inadequate facilities and infrastructure such as smartphones and unstable internet networks. In addition, parental participation and the unpreparedness of parents in assisting the learning process also affected teachers in the learning process (Wuladari et al., 2020). Students were sometimes misinformed because of the inadequate signal. As a result, they could not submit the assignments on time. In addition, teachers must check many projects, making gadget storage space increasingly limited. The application of online learning also made educators rethink the learning models and methods. They had to change the learning model (Siahaan, 2020). There is an assumption that when the online teaching and learning process during the COVID-19 pandemic occurs in the long term, it impacts not only the physical aspect of students but also their mental condition.

A crucial problem that deserves attention is parents' unpreparedness to accompany their children to participate in the online learning process, especially for elementary school children. On the other hand, the Child Protection Law states that education right to children deserves attention for its fulfillment. Education will build children's character, especially in intellectual and emotional intelligence. So that the education implementation is essential, although there is socialization restriction during the Covid-19 Pandemic. Therefore, online learning is a solution to fulfill education for children.

The implementation of online learning certainly requires the active role of parents or families in accompanying their children so that the fulfillment of rights for children can run optimally. Therefore, the role of TP-PKK to assist the implementation of online education for children during the COVID-19 pandemic is crucial. Based on the reality above, this paper aims to optimize the role of TP PKK in fulfilling the right to education for children during the COVID-19 pandemic.

The Role of Family Welfare Movement Team (TP-PKK) in Creating Child Protection in Fulfillment of Education Rights During the Covid-19 Pandemic 


\section{Target Solution}

This paper built the motivation in parents or families through the TP-PKK's role. The authors did legal counseling on child protection to fulfill the right to education during the covid-19 pandemic.

\section{METHOD}

This activity used a community empowerment approach. The target was mothers in West Kalimantan TPPKK through legal counseling. Legal counseling is a policy to develop people's cultural attitudes to be obedient and obedient to the law (Puslitbang Hukum and R, 2018). Counseling methods can be carried out in various forms, as illustrated in the following chart (Yenny, Yuliastini, and Setiawati, 2020).

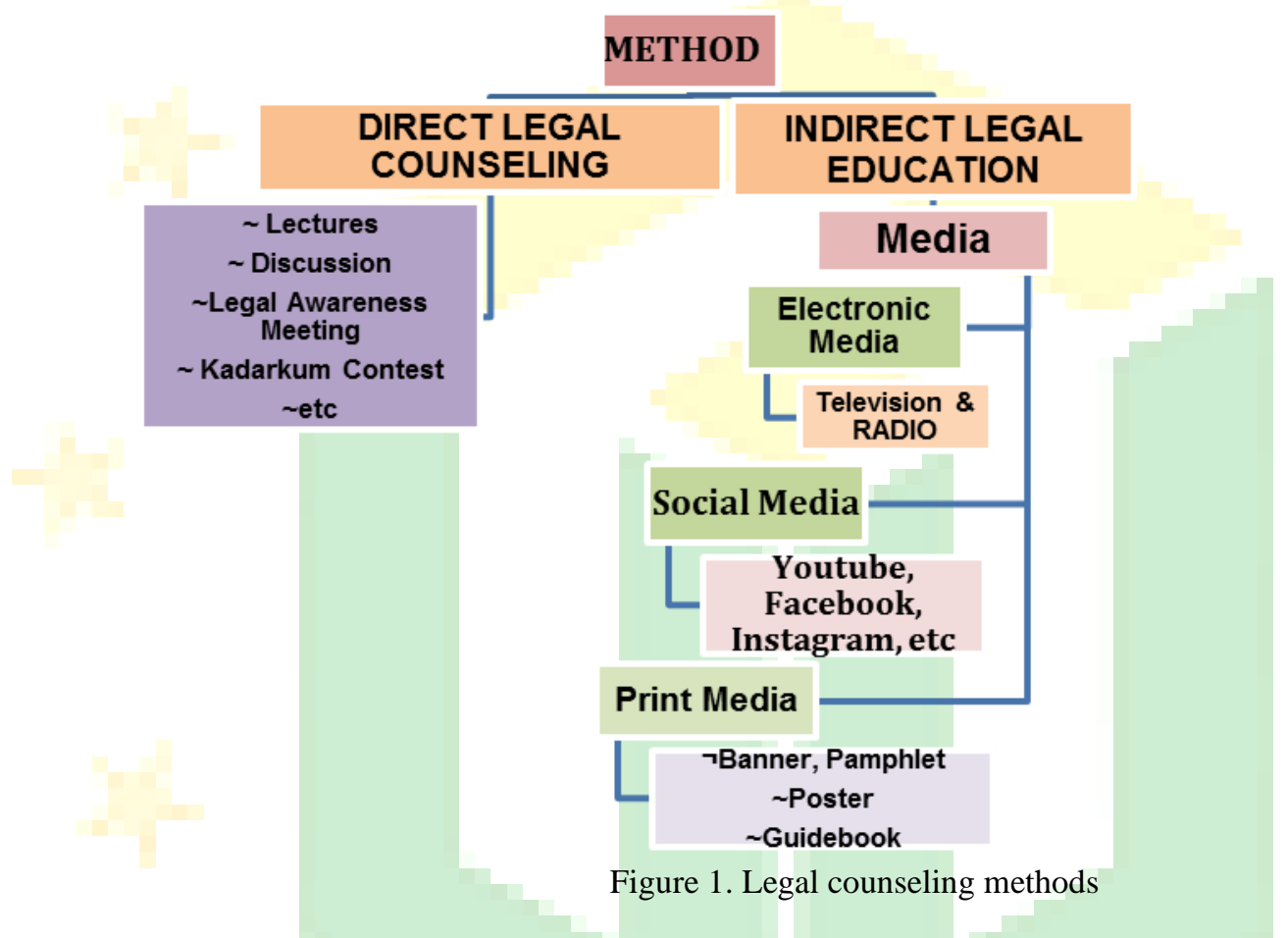

Legal counseling can be an effort to develop a legal culture in the community (AS and Setiawati, 2019). It must be carried out by carrying out the purpose and character simultaneously. Its purpose is to build public legal awareness, especially in child protection, to fulfill the right to education. It is necessary to create motivation for parents or families to understand the concept of child protection through a parenting approach with love and affection so that parents can assist in the fulfillment of the right to education for children. Legal counseling activities were carried out in lectures and discussions through zoom meetings.

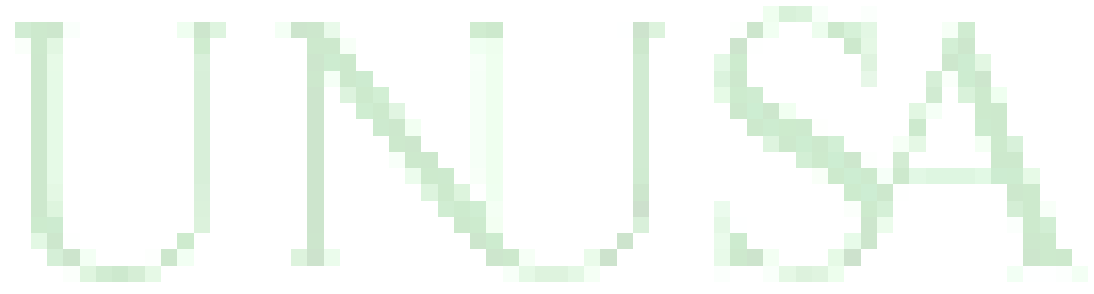

The Role of Family Welfare Movement Team (TP-PKK) in Creating Child Protection in Fulfillment of Education Rights During the Covid-19 Pandemic 


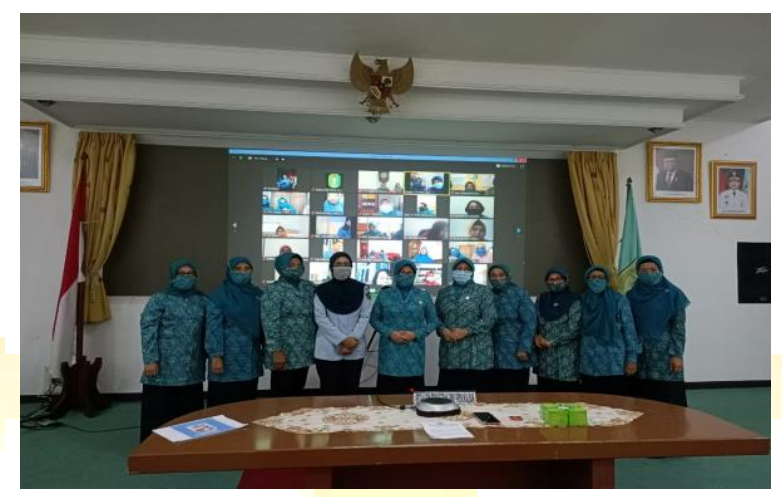

Figure 2. The Chairman of West Kalimantan TP-PKK opened online legal counseling

\section{RESULTS AND DISCUSSION}

\section{Right to Children's Education in the Perspective of Child Protection}

Education is one part of human rights (Fattah, 2017). Article 12 of the Law Number 39/1999 concerning Human Rights states that "Everyone has the right to protection of his self-development, to obtain an education, to educate himself, and to improve the quality of his life to become responsible, content, and prosperous people, in accordance with his human rights". The law's mandate aligns with schools' function in determining children's future. The article above has provided a sign that primary education is a right for children to achieve under any conditions. Education is a crucial means for human survival. The sector can create human intelligence in life (Sirait, 2017). The right to primary education is the State's responsibility in its implementation and management. The right to education requires the State to prepare an adequate education system (Fattah, 2017).

The State's obligation related to human rights is to protect, promote, fulfill and respect. The State has a responsibility that everyone has the right to education without discrimination. In addition, the State must combat all existing injustices in accessing education. It can be realized through making regulations or other means to promote equality in education (Itasari, 2020). The Nine Year Basic Education Programme is a Government policy to fulfill education rights. It is a national movement based on Law Number 20 of 2003 on the National Education System.

Children are the main priority in education regarding child protection because they are very vulnerable to human rights violations. Children require adult assistance in protecting their rights. Child protection not only reaches the fulfillment of the right to life but also includes all activities to guarantee and protect their rights. So that they can grow, develop, and participate optimally following human dignity (Sirait, 2017). In addition, they must receive protection from violence and discrimination, especially in education rights. The rights to education are part of economic, social, and cultural rights. The fulfillment of rights to education is part of the State's obligation to its people (Itasari, 2020).

\section{Children's education during the Covid-19 pandemic}

During the COVID-19 Pandemic, life and economic activities must continue. All countries, including Indonesia, are ready to face the new normal. The impact of COVID-19 has forced society into new conditions. Globally, social life creates a new order called new normal (Habibi, 2020). The covid-19 pandemic has led to various policies to break the chain of the spread of the COVID-19 virus in Indonesia. One of the efforts made by the government in Indonesia is policy to physical distancing. Physical distancing is an appeal to maintain distance between people, avoid activities in all forms of crowds, and avoid gatherings involving many people.

The COVID-19 pandemic also impacts in education aspect. With the social distancing, the Ministry of Education in Indonesia issued a policy by closing schools and replacing the teaching and learning process

The Role of Family Welfare Movement Team (TP-PKK) in Creating Child Protection in Fulfillment of Education Rights During the Covid-19 Pandemic 
using an online system. Students and teachers sometimes face various problems during online learning. In addition, parents must concern about the family economy and accompanying children to study. They have to increase the family income so that their children can continue to learn online. Furthermore, they must transform and adapt to become mentors for their children.

The Covid-19 pandemic is an opportunity to make every parent aware that the children's education is not the teachers' responsibility only. Learning is a process to change attitudes and behavior through teaching and training. Parents are role models for changing attitudes in students to deal with problems. Parents should be able to re-learn with their children at home. At the same time, they must instill a positive mindset to face the pandemic. Students must be accustomed to being lived new normal as a pattern of life with strict protocols (Siahaan, 2020).

\section{The Role of the TP-PKK through the Child and Adolescent Parenting Program to Realize Children's} Education.

Family Welfare Empowerment (here and after called with PKK) is a social organization that is a national movement for family development. It is based on Pancasila and the 1945 Constitution of the Republic of Indonesia. It carries out continuous activities to simultaneously collect, mobilize and foster the community by implementing 10 Main Programs of PKK. The target of PKK is the family as the smallest unit in society. The purposes of PKK are to create a prosperous family that always lives in a peaceful, orderly, and prosperous atmosphere in the Unitary State of the Republic of Indonesia (Anshar, 2017).

PKK is a community-based education, a manifestation of the democratization of education through expanding educational services for the community's benefit. Empowerment is the concept we use most often in setting up a better direction.

PKK recruits members to the low levels of society. PKK is expected to be able to lead to a prosperous family condition. A prosperous family condition is a family that can meet basic human needs both materially, socially, mentally, and spiritually. Meanwhile, the empowered family is a family that lives in prosperity, progress, and independence (Handayani, 2008). One of the PKK roles is fostering law-conscious family groups formed through cadres. The program is very strategic for disseminating and providing legal education to the community about the importance of fulfilling the right to education for children during the covid-19 pandemic. The TP-PKK forms this program from the village to the Regency/City PKK to protect the children. In addition, their rights to education are fulfilled, although parents face many challenges regarding access to education for their children, which must be done online.

Legal counseling to motivate parents or families to assist their children's education rights during the COVID19 pandemic was carried out in an integrated manner by involving the TP-PKK in regencies or cities throughout West Kalimantan. The Chairman of West Kalimantan TP-PKK opened this activity. The counseling presented psychologists and legal counselors from the Regional Office of the Ministry of Justice and Human Rights of West Kalimantan and the PPM Team of the Faculty of Law, Panca Bhakti University, Pontianak, through a zoom meeting. Figure 3 shows online legal counseling .

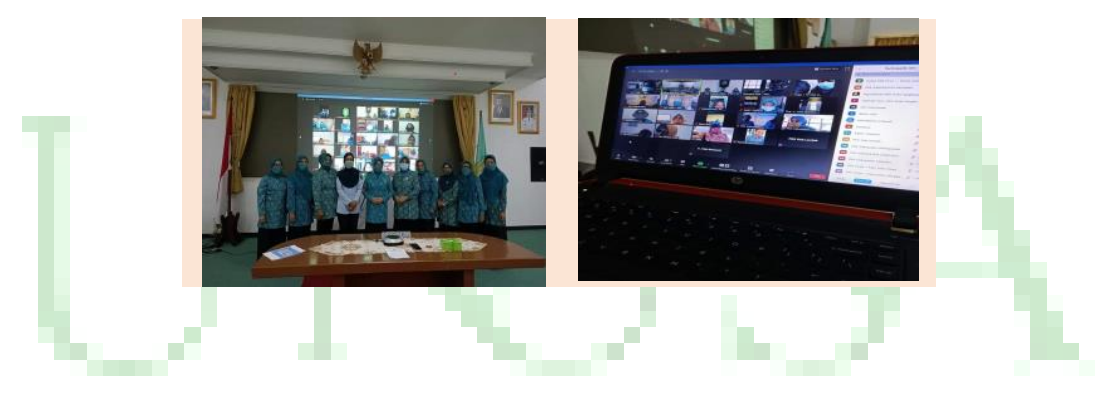

The Role of Family Welfare Movement Team (TP-PKK) in Creating Child Protection in Fulfillment of Education Rights During the Covid-19 Pandemic 

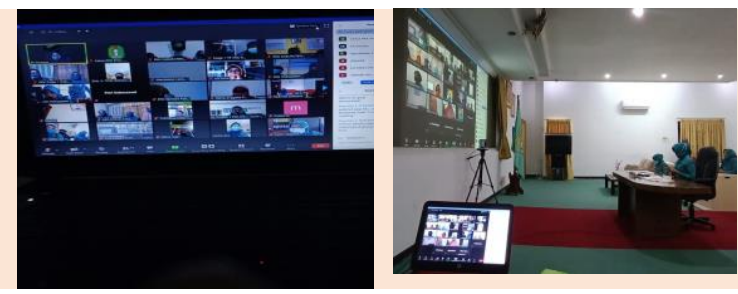

Figure 3. Legal counseling to motivate parents or families to assist their children's education rights during the COVID19 pandemic

This activity changed the perception that education is a right for every child, even during the COVID-19 pandemic. The pandemic impacted the suboptimal learning process. Still, parents or families must always be prepared to face the online learning process with all the obstacles. Respondents' opinions regarding the importance of parental assistance in the online learning process during the Covid-19 Pandemic were in the following table 1.

Table.1 Respondents' Opinion regarding The Importance of Parental Assistance in the Online Teaching and Learning Process during the Covid-19 Pandemic

\begin{tabular}{cllcc}
\multicolumn{1}{c}{ Num } & \multicolumn{1}{c}{ Alternative Answers } & Frequency & Percentage (\%) \\
\hline $\mathbf{1}$ & Important & 34 & 100 \\
$\mathbf{2}$ & Not Important, because it is the teacher's job & 0 & 0 \\
& Total & 34 & 100 \\
\cline { 2 - 4 }
\end{tabular}

Table.1 shows that parent or family assistance in implementing children's online learning processes during the covid-19 pandemic is essential to fulfilling children's right to education. In addition, the teacher's main task is carrying out education and teaching. However, parents or families faced obstacles in assisting children during the online learning process, as revealed in table 2.

Table.2 Obstacles faced by parents or families in assisting children in the online learning process during the Covid-19 Pandemic

\begin{tabular}{|c|c|c|c|}
\hline Num & Obstacles & Frequency & Percentage $(\%)$ \\
\hline 1 & Difficulty in sharing time due to work or household affairs & 8 & 23.53 \\
\hline 2 & Lack of understanding regarding the learning materials & 10 & 29.41 \\
\hline 3 & Lack of understanding regarding online learning system & 6 & 17.65 \\
\hline 4 & Lack of wifi devices and costs & 4 & 11.76 \\
\hline \multirow[t]{2}{*}{5} & Others ( a combination of alternatives $1,2,3$ and 4 ) & 6 & 17.65 \\
\hline & Total & 34 & 100.00 \\
\hline
\end{tabular}

Table.2 shows parents' unpreparedness in online learning. In this activity, psychologists taught the importance of motivating parents or families to fulfill the children's rights to education during this covid-19 pandemic.

The COVID-19 pandemic has given wisdom to all community members, including parents or families with children in the elementary or junior high school levels. Parents must know and be willing to learn with the online learning system. TP-PKK has a strategic role in building motivation for parents/families to accompany and direct their children in the online learning process with love and affection through the parenting program in children and teenagers. As a result, all individuals can face the COVID-19 pandemic.

The results of this activity certainly cannot be seen directly. Still, it is hoped that it can sustainably take place and continue to the family levels in the community. So there is an understanding that the fulfillment of education rights in children is essential to be fulfilled.

Pancasila (n): the official, foundational philosophical theory of Indonesia

\section{CONCLUSIONS AND SUGGESTION}

TP-PKK has a role in creating child protection in fulfillment of education rights during the Covid-19

The Role of Family Welfare Movement Team (TP-PKK) in Creating Child Protection in Fulfillment of Education Rights During the Covid-19 Pandemic 
pandemic. Legal counseling could be carried out widely and sustainably to motivate parents or families to assist their children in the online learning process, so child protection is realized.

\section{ACKNOWLEDGMENT}

The authors would like to thank the Dean of the Faculty of Law, Panca Bhakti University, Pontianak, for funding this community service activity.

\section{REFERENCES}

Anshar, M. (2017) Analisis Program Pemberdayaan Kesejahteraan Keluarga (PKK) Dalam Upaya Peningkatan Kesejahteaan Ekonomi Warga Di Kelurahan Sei Kera Hilir II Medan. doi:10.1017/CBO9781107415324.004.

AS, Y. and Setiawati, R. (2019) "Penyuluhan Hukum sebagai Media Komunikasi Mencegah Kekerasan Terhadap / Oleh Guru Guna Mewujudkan Perlindungan Guru Berkeadilan,” in The 1st National Conference on Education, Social Science, and Humaniora "The Integration of Character Education in The 21st Century Innovative Skills", pp. 68-76.

Fattah, V. (2017) "Hak Asasi Manusia Sebagai Jus Cogens Dan Kaitannya Dengan Hak Atas Pendidikan," Yuridika, 32(2), p. 352. doi:10.20473/ydk.v32i2.4775.

Habibi, A. (2020) "Normal Baru Pasca Covid-19," Journal.Uinjkt.Ac.Id, 4(1), pp. 197-202. doi:10.15408/adalah.v4i1.15809.

Hakim, L. (2016) "Pemerataan akses pendidikan bagi rakyat sesuai dengan amanat Undang-Undang Nomor 20 Tahun 2003 tentang Sistem Pendidikan Nasional," EduTech: Jurnal Ilmu Pendidikan Dan Ilmu Sosial, 2(1), pp. 53-64.

Handayani, T. (2008) "Pemberdayaan Dan Kesejahteraan Keluarga (PKK) Di Kota Malang: Dalam Perspektif Kajian Budaya," E-Journal of Cultural Studies.

Harirah, Z. (2020) "Merespon Nalar Kebijakan Negara Dalam Menangani Pandemi Covid 19 Di Indonesia," Jurnal Ekonomi dan Kebijakan Publik Indonesia, 7(1), pp. 36-53. doi:10.24815/ekapi.v7i1.17370.

Isbaniah, F. and Susanto, A.D. (2020) "Pneumonia Corona Virus Infection Disease -19 ( COVID-19)," J Indon Med Assoc, 70(4), pp. 87-94.

Itasari, E.R. (2020) "Hak Pendidikan Di WIlayah Perbatasan Dalam Kerangka Konstitusi Republik Indonesia,” Jurnal Media Komunikasi Pendidikan Pancasila dan Kewarganegaraan, 2(1), pp. 80100. doi:10.23887/jmpppkn.v2i1.85.

Kusnayat, A. (2020) "Pengaruh Teknologi Pembelajaran Kuliah Online Di Era Covid-19 Dan Dampaknya Terhadap Mental Mahasiswa," EduTeach: Jurnal Edukasi dan Teknologi Pembelajaran, 1(2), pp. $153-165$.

Nurkholis (2020) "Dampak Pandemi Novel-Corona Virus Disiase ( Covid-19) Terhadap Psikologi Dan Pendidikan Serta Kebijakan Pemerintah," Jurnal PGSD, 6(1), pp. 39-49. Available at: https://ejournal.umc.ac.id/index.php/JPS.

The Role of Family Welfare Movement Team (TP-PKK) in Creating Child Protection in Fulfillment of Education Rights During the Covid-19 Pandemic 
Puslitbang Hukum, B.P.H.N. and R, K. (2018) Implikasi Penyuluhan Langsung Terhadap Peningkatan Kesadaran Hukum Masyarakat.

Salim, M. (2018) "Akses Terhadap Keadilan Dan Pemberdayaan Hukum Sebagai Pendekatan Untuk Pengembangan Hukum Bagi Orang Miskin Dan Yang Terpinggirkan,” Al Daulah: Jurnal Hukum Pidana dan Ketatanegaraan, 7(1), pp. 153-162. doi:10.24252/ad.v7i1.5384.

Siahaan, M. (2020) “Dampak Pandemi Covid-19 Terhadap Dunia Pendidikan,” Jurnal Kajian Ilmiah, 1(1), pp. 73-80. doi:10.31599/jki.v1i1.265.

Sirait, S.C. (2017) "Tanggung Jawab Pemerintah Untuk Memberikan Pendidikan Kepada Anak Terlantar Dalam Perspektif Undang-Undang Perlindungan Anak'," De Lega Lata, 2(1), pp. 158-182. doi:10.31219/osf.io/75tp2.

Wuladari, M.A. et al. (2020) "Analisis Pembelajaran 'Daring' pada Guru Sekolah Dasar di Era Covid-19," Jurnal Ilmiah P2M STKIP Siliwangi P2M STKIP Siliwangi, 7(2), pp. 164-168.

Yenny, A.S., Yuliastini, A. and Setiawati, R. (2020) "Membangun Kesadaran Hukum Tentang Perlindungan Anak Bagi Guru," Journal of Character Education Society, 3(3), pp. 8-10. Available at: http://journal.ummat.ac.id/index.php/JCES/article/view/2580.

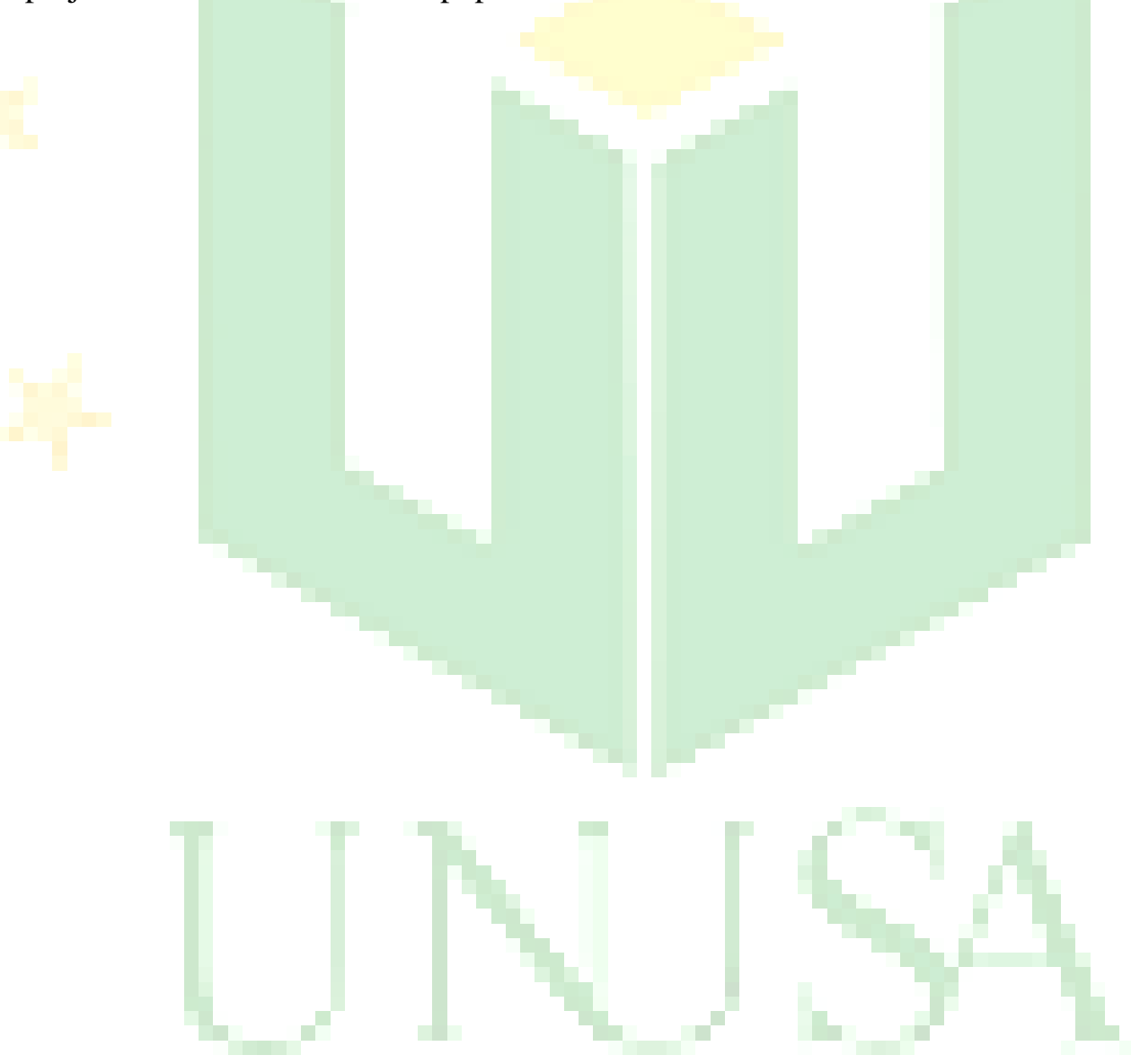

The Role of Family Welfare Movement Team (TP-PKK) in Creating Child Protection in Fulfillment of Education Rights During the Covid-19 Pandemic 